\title{
USPOREDBA RAZINE ZNANJA MEĐU UČENICIMA ZDRAVSTVENE ŠKOLE SPLIT I STUDENATA SESTRINSTVA SVEUČILIŠNOG ODJELA ZDRAVSTVENIH STUDIJA U SPLITU O KARDIOPULMONALNOJ REANIMACIJI
}

\author{
DIANA ELEZ ${ }^{1}$, RAHELA ORLANDINI ${ }^{2}$, MIHAJLO LOJPUR ${ }^{2,3}$, MARIO MARENDIĆ ${ }^{2}$
}

Cilj: Usporediti znanja učenika Zdravstvene škole Split i studenata Sveučilišnog odjela zdravstvenih studija u Splitu o kardiopulmonalnoj reanimaciji.

Metode: U ovom istraživanju sudjelovalo je 186 ispitanika, 94 studenta i 92 učenika. Korišten je mjerni instrument upitnik CAEPCR. Čimbenici uključenja ispitanika bili su dob >18 godina, bez dodatnih čimbenika isključenja.

Rezultati: Zbrajanjem ispravnih odgovora u pitanjima znanja, dokazali smo statističku značajnu razliku prema ukupnom zbroju ispravnih odgovora na pitanja znanja između učenika i studenata $(Z=2,96 ; r=0,217 ; P=0,003)$. Medijan ukupnog zbroja točnih odgovora u učenika Zdravstvene škole Split iznosi 6, a u studenata na Sveučilišnom odjelu zdravstvenih studija u Splitu iznosi 5. Postoji statistički značajna, slaba negativna korelacija ukupnog zbroja pozitivnih odgovora sa životnom dobi ispitanika ( $\rho=-0,195$; $P=0,008)$. Raspodjela ukupnog zbroja ispravnih odgovora na pitanja znanja prema 5 formiranih skupina statistički se značajno razlikovala između ustanova.

Zaključak: S obzirom na dobivene rezultate možemo zaključiti da je razina znanja veća kod ispitanika Zdravstvene srednje škole u odnosu na studente Sveučilišnog odjela zdravstvenih studija u Splitu. Tom rezultatu doprinosi razlika u provedenoj edukaciji prikazana u nastavnim planovima i programima. Zbog razlike u edukaciji odnosno u trajanju edukacije $i$ vremena protijeka od edukacije, potrebno je provesti daljnje detaljnije istraživanje o utjecaju tih čimbenika na znanje.

Ključne riječi: KARDIOPULMONALNA REANIMACIJA, MEDICINSKA SESTRA, SMJERNICE, ZNANJE

\section{UVOD}

U medicini svakodnevno dolazi do novih spoznaja, stoga su zdravstveni djelatnici dužni pratiti te promjene i u skladu s promjenama se obrazovati. Kardiopulmonalna reanimacija (KPR) predstavlja zbir različitih postupaka i drugih terapijskih mjera kojima je cilj spriječiti srčani zastoj ili prestanak disanja, odnosno ponovno uspostavljanje pre-

${ }^{1}$ Poliklinika J\&J Medici, Split, Republika Hrvatska ${ }^{2}$ Sveučilište u Splitu,

Sveučilišni odjel zdravstvenih studija, Split

${ }^{3}$ Klinički bolnički centar Split

Adresa za dopisivanje:

Mario Marendić, mag. med. techn.,

https://orcid.org/0000-0002-2968-1175

Sveučilište u Splitu,

Sveučilišni odjel zdravstvenih studija

21000 Split, Ruđera Boškovića 35,

E-mail: mmarendic@ozs.unist.hr kinutog rada srca (cirkulacija) i disanja (1). Edukacija se može provoditi u vidu tečajeva i prezentacija koje organiziraju zdravstvene ustanove. Znanje iz reanimacije također neprekidno napreduje te se kliničke ustanove redovito obnavljaju kako bi zdravstvenim djelatnicima omogućile primjenu najboljih postupaka u liječenju pacijenata (2). Europsko vijeće za reanimatologiju (engl. European Resuscitation Council; ERC) obnavlja smjernice svakih pet godina, a smjernice nastaju kao rezultat sustavnih pregleda literature o širokom opsegu tema koje se odnose na KPR. Poput prethodnih, i ove se smjernice temelje na najnovijem dokumentu Međunarodnog sporazuma o znanstvenom pristupu oživljavanju s preporukama za liječenje (engl. International Consensus on CPR Science with Treatment Recommendations; CoSTR) i označavaju sporazum između članova
ERC-a $(1,2)$. U petogodišnjem razdoblju između objavljivanja smjernica, privremeni znanstveni izvještaji obavještavaju zdravstvene radnike o novim načinima liječenja koji značajno mogu utjecati na ishode (2).

Čanađija M. je u Zagrebu 2014. godine proveo retrospektivno istraživanje između polaznika tečaja neposrednog održavanja života (engl. Immediate Life Support; ILS). Sudionici istraživanja su bili medicinske sestre/medicinski tehničari srednje stručne spreme i prvostupnice/prvostupnici sestrinstva ( $\mathrm{n}=153)$. Dobiveni rezultati su pokazali da polaznici pristupaju tečaju s podjednakom razinom znanja. U navedenom istraživanju je u obje skupine nađena statistički značajno viša razina znanja po položenom tečaju, u usporedbi sa znanjem prije provedenog tečaja (3). Zaključak istraživanja je 
da dobiveni rezultati idu u prilog tečaju u cjelini kao obliku edukacije na kojem polaznici postižu značajan napredak u znanju bez obzira na stupanj obrazovanja. Također, autor ističe zabrinutost o nepronalaženju statistički značajne razlike u razini znanja prema stupnju obrazovanja, kako prije, tako ni po provedenom tečaju. Uzrok tome treba vjerojatno tražiti u programu formalnog obrazovanja medicinskih sestara na studijima sestrinstva u Republici Hrvatskoj (3).

Učenici zdravstvenih škola u Hrvatskoj u 4. razredu srednjoškolskog obrazovanja pohađaju predmet Hitni medicinski postupci, a studenti sestrinstva na trećoj godini studija pohađaju predmet Anesteziologija, reanimatologija i intenzivno liječenje $(4,5)$. Tijekom pohađanja predmeta spomenutih predmeta, učenici i studenti se osposobljavaju za pružanje hitne medicinske pomoći po završetku svog obrazovanja $(4,5)$.

Pregledom stručne literature u Hrvatskoj, do danas nije provedeno istraživanje o znanju budućih medicinskih sestara o kardiopulmonalnoj reanimaciji; stoga je cilj ovog istraživanja usporediti znanja učenika Zdravstvene škole Split i studenata Sestrinstva Sveučilišnog odjela zdravstvenih studija Split o kardiopulmonalnoj reanimaciji.

\section{ISPITANICI I METODE}

\section{Uzorak ispitanika}

Istraživanje je provedeno u akademskoj godini 2018./2019., tijekom svibnja, jednokratnim anketiranjem učenika četvrtog i petog razreda srednje Zdravstvene škole u Splitu, smjera medicinska sestra - medicinski tehničar opće zdravstvene njege, te studenata prve, druge $\mathrm{i}$ treće godine Sveučilišnog odjela zdravstvenog studija u Splitu, preddiplomskog studija Sestrinstvo. Kriteriji uključenja ispitanika bili su: $>18$ godina, nije bilo dodatnih kriterija isključenja. Ispitanici su bili upoznati s ciljem istraživanja, dane su im upute za sudjelovanje te im je naglašena dobrovoljnost sudjelovanja $\mathrm{u}$ istraživanju, kao i anonimnost samog upitnika. Pred početak istraživanja ispitanici su potpisali informirani pristanak.

\section{Mjerni instrument}

Mjerni instrument je anonimni upitnik CAEPCR (engl. Knowledge and Attitude of Nurses in the Event of a Cardiorespiratory Arrest - izvorno španjolski jezik), koji se sastoji od tri dijela (6). U ovom istraživanju obuhvatili smo samo dva dijela upitnika, demografske odrednice ispitanika i pitanja znanja. Prvi, opći dio upitnika ispituje demografske odrednice ispitanika (dob, spol, ustanova obrazovanja, godinu školovanja i vrijeme proteklo od pohađanja predmeta, i potrebu o dodatnoj edukaciji). Drugi dio upitnika sadrži 11 pitanja o znanju, višestrukog izbora gdje je točan samo jedan odgovor. Za potrebe ovog istraživanja, a uz prethodno odobrenje autora upitnika, koristili smo prevedenu verziju CAEPCR upitnika na hrvatski jezik (6). U ovom istraživanju uzeli smo u obzir smjernice ERC-a za 2015. godinu, s obzirom da su autori Tíscar-Gonzalez i sur. provodili istraživanje prema ERC smjernicama za 2010. godinu $(3,6)$.

\section{Statistička obrada podataka}

Za povezanost kvalitativnih varijabli, koristili smo $\chi 2$ test i logističku regresiju. Za korelaciju kvantitativnih varijabli koristili smo Spearmanov koeficijent korelacije ( $\rho)$. Mann Whitney testom smo testirali razlike između dviju skupina, a Kruskal Wallis testom između više skupina. Normalnost razdiobe testirana je Kolmogorov-Smirnov testom. Podatci su obrađeni u IBM SPSS 23. programu za statističku obradu podataka, a rezultati su interpretirani na razini značajnosti $\mathrm{P}<0,05$ (7).

\section{REZULTATI}

U ovom istraživanju sudjelovalo je 186 ispitanika. Od ukupnog broja ispitanika bilo je 24 (13\%) muškaraca i 162 (87\%) žena. U Zdravstvenoj školi Split četvrti i peti razred pohađa ukupno 106 učenika. Ovo istraživanje je obuhvatilo 92 učenika Zdravstvene škole Split (postotak odaziva $86,8 \%$ ), od čega su 74 $(80 \%)$ ispitanica žene, a $18(20 \%)$ ispitanika muškarci (Slika 1).

Na Sveučilišnom odjelu zdravstvenih studija u Splitu, na preddiplomskom studiju Sestrinstva studira ukupno 115 studenata. Ovo istraživanje je obuhvatilo 94 ispitanika Sveučilišnog odjela zdravstvenih studija u Splitu (postotak odaziva ispitanika $81,7 \%$ ), od čega su 88 $(94 \%)$ ispitanica žene, a 6 (6\%) ispitanika muškarci (Slika 1). Najveći broj ispitanika bio je u dobi od 19 godina, i to 54 ispitanika (29\%). Raspodjela odgovora na pitanje "Vrijeme proteklo od pohađanja predmeta sa sadržajem kardiopulmonalne reanimacije?" u odnosu na ispitivane

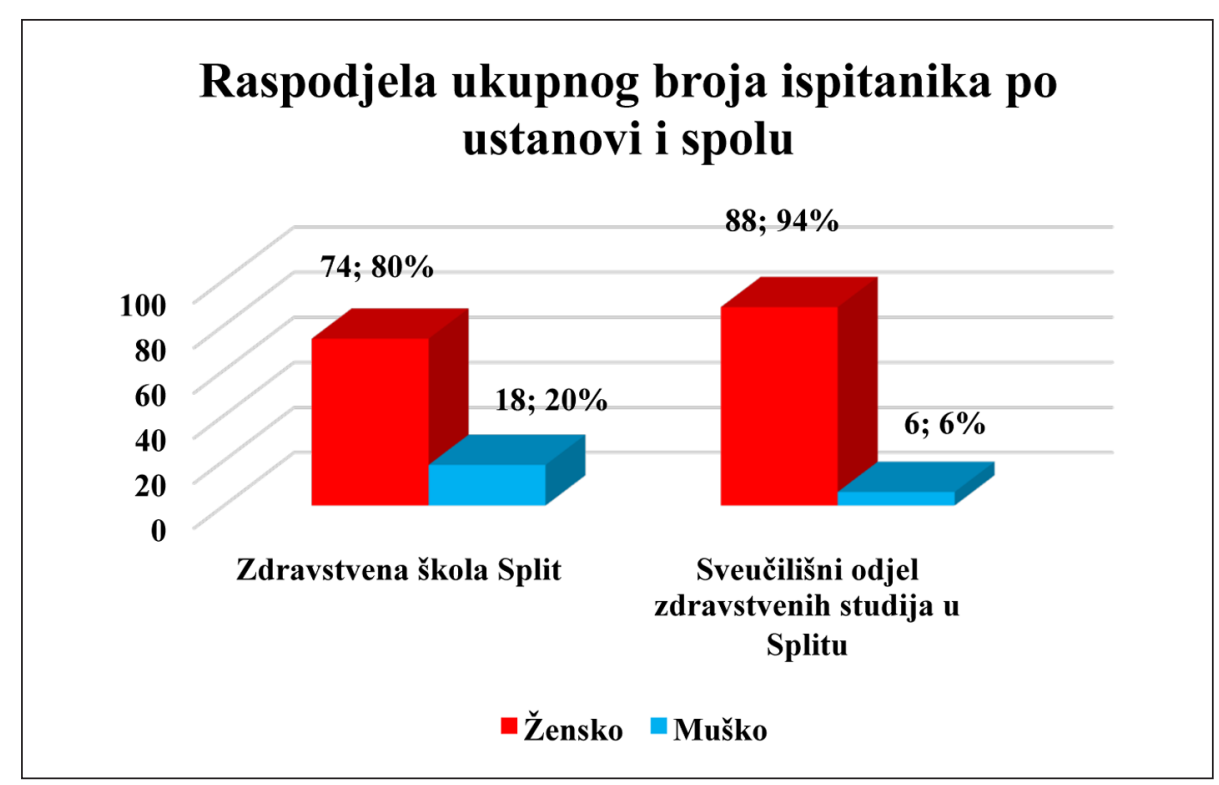

Slika 1.

Raspodjela ukupnog broja ispitanika po ustanovi i spolu (\%) 
Tablica 1.

Demografske karakteristike ispitanika ukupno i u odnosu na ispitane skupine

Ustanova školovanja

Karakteristika

Ukupno $(\mathrm{n}=186)$

Zdravstvena škola Split

Sveučilišni odjel

$\mathrm{P} *$ $(\mathrm{n}=92)$

Spol; n (\%)

$\begin{array}{llll}\text { Žensko } & 162(87) & 74(80) & 88(94) \\ \text { Muško } & 24(13) & 18(20) & 6(6)\end{array}$

Vrijeme proteklo od pohađanja predmeta sa sadržajem

kardiopulmonalne reanimacije?

$\begin{array}{rllr}<6 \text { mjeseci } & 122(65,6) & 49(53.3) & 73(77,7) \\ >2 \text { godine } & 4(2,2) & 2(2,2) & 2(2,1) \\ 1 \text { do } 2 \text { godine } & 15(8,1) & 9(9,8) & 6(6,4) \\ 6 \text { mjeseci do } 1 \text { godine } & 37(19,9) & 32(34,8) & 5(5,3) \\ \text { Nisam dosada pohađao/la takav predmet } & 8(4,3) & 0 & 8(8,5)\end{array}$

Koliko često bi se po Vama trebali održavati tečajevi

kardiopulmonalne reanimacije?

$\begin{array}{rlll}<6 \text { mjeseci } & 52(28) & 29(31,5) & 23(24,5) \\ >2 \text { godine } & 8(4,3) & 5(5,4) & 3(3,2) \\ 1 \text { do } 2 \text { godine } & 60(32,3) & 27(29,3) & 33(35,1) \\ 6 \text { mjeseci do } 1 \text { godine } & 66(35,5) & 31(33,7) & 35(37,2) \\ \text { nikada } & 0 & & \end{array}$

Osjećate li ste osposobljeno za pružanje kardiopulmonalne reanimacije?

\begin{tabular}{rlcc} 
Da & $63(33,9)$ & $35(38)$ & $28(29,8)$ \\
Ne & $15(8,1)$ & $4(4,3)$ & $11(11,7)$ \\
Smatram da mi je potrebna dodatna edukacija & $108(58,1)$ & $53(57,6)$ & $55(58,5)$ \\
\hline
\end{tabular}

$* \chi 2$

skupine statistički se značajno razlikovala $(\chi 2=32,9 ; \mathrm{P}<0,001)$ (skupina ispitani$\mathrm{ka}>2$ i 1 do 2 godine su spojene u jednu) (Tablica 1).

Udio ispitanika s vremenom 6 mjeseci do 1 godine u Zdravstvenoj školi Split 6,5 puta je veći nego udio istih na Sveučilišnom odjelu zdravstvenih studija u Splitu (Tablica 1). Raspodjela odgovora u odnosu na pitanje "Koliko često bi se po Vama trebali održavati tečajevi kardiopulmonalne reanimacije?" nije se statistički značajno razlikovala između ispitivanih skupina ( $\chi 2=2,0 ; \mathrm{P}=0,570$ ) (Tablica 1). Raspodjela odgovora na pitanje "Osjećate li ste osposobljeno za pružanje kardiopulmonalne reanimacije?" u odnosu na ispitivane skupine nije se statistički značajno razlikovala $(\chi 2=4,06$; $\mathrm{P}=0,131)$ (Tablica 1).

Udio ispravnih odgovora na pitanje 1. "Pacijentov član obitelji Vam kaže da pacijent leži na tlu i ne reagira na podražaj, vi ćete:" u ispitanika Zdravstvene škole Split 1,7 puta je veći, nego u ispitanika Sveučilišnog odjela zdravstvenih studija u Splitu ( $\chi 2=8,6 ; \mathrm{P}=0,003)$ (Tablica 2). Omjer izgleda za ispravan odgovor na isto pitanje 2,5 puta je veći u skupini srednjoškolaca nego u skupini studenata $(\mathrm{P}=0,002)$ (Tablica 2$)$.

Udio ispravnih odgovora na pitanje 9. "Uzimajući u obzir način primjene lijeka tijekom kardiorespiratornog zastoja, točno je da se:" u ispitanika Zdravstvene škole Split za 1,2 puta je veći udio ispravnih odgovora nego kod ispitanika na Sveučilišnom odjelu zdravstvenih studija u Splitu ( $\chi 2=5 ; \mathrm{P}=0,025)$, a broj neispravnih odgovora $\mathrm{u}$ skupini studenata za 1,8 puta je veći nego u srednjoškolaca $(\chi 2=5,0 ; \mathrm{P}=0,025)$ (Tablica 2). Omjer izgleda za ispravan odgovor na isto pitanje za 2,3 puta je veći u skupini srednjoškolaca nego u skupini studenata $(\mathrm{P}=0,017)$ (Tablica 2).

Udio ispravnih odgovora na pitanje 10. "Lijekovi koji se primjenjuju intravenozno trebaju:" u ispitanika Zdravstvene škole Split 4 puta je veći udio ispravnih odgovora nego u ispitanika na Sveučiliš- 
Tablica 2.

Prikaz broja (\%) ispravnih odgovora prema pitanju u odnosu na ustanovu ispitivanih skupina (Zdravstvena škola Split i Sveučilišni odjel zdravstvenih studija)

\begin{tabular}{|c|c|c|c|c|c|c|c|}
\hline $\begin{array}{l}\text { Redni } \\
\text { Broj } \\
\text { pitanja }\end{array}$ & Pitanje znanja & $\begin{array}{l}\text { Ukupno } \\
(\mathrm{n}=186)\end{array}$ & $\begin{array}{l}\text { Zdravstvena } \\
\text { škola Split }\end{array}$ & $\begin{array}{l}\text { Sveučilišni odjel } \\
\text { zdravstvenih } \\
\text { studija u Splitu }\end{array}$ & $\chi 2 ; \mathrm{P}^{*}$ & OR; 95\% CI & $\mathrm{P}^{* *}$ \\
\hline 1. & $\begin{array}{l}\text { Pacijentov član obitelji Vam kaže da pacijent } \\
\text { leži na tlu i ne reagira na podražaj, vi ćete: }\end{array}$ & $80(43)$ & $50(54)$ & $30(32)$ & 8,$6 ; 0,003$ & 2,$5 ; 1,4-4,6$ & 0,002 \\
\hline 2. & Utvrdili ste da je pacijent bez svijesti, vi ćete: & $151(81)$ & $78(85)$ & $73(78)$ & 1,$11 ; 0,291$ & & \\
\hline 3. & $\begin{array}{l}\text { Nakon što ste utvrdili prestanak disanja i } \\
\text { izostanak srčanog rada, došli ste do zaključka } \\
\text { da je pacijent u kardiorespiratornom zastoju } \\
\text { te započinjete KPR. Stoga morate znati da se } \\
\text { optimalna kompresijska tehnika prsnog koša } \\
\text { sastoji od: }\end{array}$ & $77(41)$ & $36(39)$ & $41(44)$ & 0,$223 ; 0,637$ & & \\
\hline 4. & $\begin{array}{l}\text { Prema smjernicama ERC-a za } 2015 \text { godinu, } \\
\text { točan omjer kompresija/ventilacije u KPR-u je: }\end{array}$ & $172(92)$ & $87(95)$ & $85(90)$ & 0,$627 ; 0,428$ & & \\
\hline 5. & $\begin{array}{l}\text { Važne promjene dodane u KPR smjernicama } \\
\text { uključuju: }\end{array}$ & $116(62)$ & $58(63)$ & $58(62)$ & 0,$001 ; 0,97$ & & \\
\hline 6. & $\begin{array}{l}\text { Tijekom liječenja srčanog zastoja povezanim } \\
\text { s ventrikularnom fibrilacijom (VF) ili } \\
\text { ventrikularnom tahikardijom (VT) bez pulsa, } 1 \\
\text { mg adrenalina se primjenjuje: }\end{array}$ & $28(15)$ & $14(15)$ & $14(15)$ & $0 ; 1$ & & \\
\hline 7. & $\begin{array}{l}\text { Da bi se postigao zadovoljavajući učinak } \\
\text { kompresija prsnog koša, kada god je moguće } \\
\text { preporuča se da: }\end{array}$ & $97(52)$ & $42(46)$ & $55(58)$ & 2,$6 ; 0,108$ & & \\
\hline 8. & Nakon izvođenja defibrilacije potrebno je: & $25(13)$ & $14(15)$ & $11(12)$ & 0,$238 ; 0,626$ & & \\
\hline 9. & $\begin{array}{l}\text { Uzimajući u obzir način primjene lijeka tijekom } \\
\text { kardiorespiratornog zastoja, točno je da se: }\end{array}$ & $137(74)$ & $75(81)$ & $62(66)$ & $5 ; 0,025$ & 2,$3 ; 1,16-4,5$ & 0,017 \\
\hline 10. & $\begin{array}{l}\text { Lijekovi koji se primjenjuju intravenozno } \\
\text { trebaju: }\end{array}$ & $29(16)$ & $23(25)$ & $6(6)$ & 10,$9 ; 0,001$ & 4,$9 ; 1,9-12,7$ & 0,001 \\
\hline 11. & $\begin{array}{l}\text { Koji je najučinkovitiji način liječenja pacijenta } \\
\text { s kardiopulnonalnim zastojem povezanim s } \\
\text { ventrikularnom fibrilacijom: }\end{array}$ & $131(70)$ & $70(76)$ & $61(65)$ & 2,$28 ; 0,131$ & & \\
\hline
\end{tabular}

* $\chi 2 ; * * \operatorname{logistička~regresija~}$

nom odjelu zdravstvenih studija u Splitu ( $\chi 2=10,9 ; \mathrm{P}=0,001)$. Omjer izgleda za ispravan odgovor na isto pitanje 4,9 puta je veći u skupini srednjoškolaca nego u skupini studenata $(\mathrm{P}=0,001)$ (Tablica 2). Nismo dokazali statistički značajnu razliku u broju ispravnih odgovora između ispitivanih skupina prema pitanjima 2,3 , 4, 6, 7, 8 i 11 (Tablica 2).

Medijan ukupnog zbroja ispravnih odgovora svih ispitanika zajedno iznosi 6 (Q1-Q3: 5-7; min-max 2-10); u učenika Zdravstvene škole Split iznosi 6 (Q1-Q3: 5-7; min-max 2-9), a u studenata na Sveučilišnom odjelu zdravstvenih studija $u$ Splitu iznosi 5 (Q1-Q3: 4-6; min-max 2-10). Postoji statistički značajna razlika prema ukupnom zbroju ispravnih odgovora između učenika i studenata $(\mathrm{Z}=2,96 ; \mathrm{r}=0,217 ; \mathrm{P}=0,003)$ (Tablica 3). Postoji statistički značajna, slaba negativna korelacija ukupnog zbroja pozitivnih odgovora sa životnom dobi ispitanika $(\rho=-0,195 ; P=0,008)$ (Tablica 3$)$.

Nismo dokazali statistički značajnu povezanost ukupnog zbroja ispravnih odgovora $s$ vremenom koje je proteklo od posljednje edukacije ( $\rho=-0,067$; $\mathrm{P}=0,364$ ) (Tablica 3). Ispitanici koji su odgovorili s 2 ili 3 ispravna odgovora priključeni su skupini koja je imala 4 ispravna odgovora, a skupinu 9 i 10 priključili smo skupini koja je imala 8 ispravnih odgovora. $\mathrm{Na}$ taj način smo dobili 5 skupina ispitanika: $\leq 4$ ispravna odgovora; 5 ispravnih odgovora; 6 ispravnih odgovora; 7 ispravnih odgovo$\mathrm{ra} ; \geq 8$ ispravnih odgovora $\mathrm{i}$ analizirali ih u odnosu na ustanovu (Tablica 3).

Raspodjela ukupnog zbroja ispravnih odgovora prema ovako formiranim skupinama statistički se značajno razlikovala između ustanova $(\chi 2=12,9 ; \mathrm{P}=0,011)$ (Tablica 3). Razlici doprinosi činjenica da je udio ispitanika s ukupnim brojem ispravnih odgovora $\leq 4$ dva puta veći na Sveučilišnom odjelu zdravstvenih studija u Splitu (31\%), nego ispitanika s istim brojem ispravnih odgovora u Zdravstvenoj školi Split (15,2\%). Razlici također doprinosi činjenica da je udio ispitanika s ukupnim brojem ispravnih odgovora $\geq 8$ u skupini srednjoškolaca $(16,3 \%) 4$ puta veći od udjela ispitanika $\mathrm{s}$ istim brojem ispravnih 
Tablica 3.

Prikaz broja ispitanika prema ukupnom broju ispravnih odgovora u odnosu na ustanove (Zdravstvena škola Split i Sveučilišni odjel zdravstvenih studija u Splitu)

\begin{tabular}{llll}
\hline & \multicolumn{3}{c}{ Broj ispitanika (\%) } \\
\cline { 2 - 4 } $\begin{array}{l}\text { Ukupan broj } \\
\text { ispravnih odgovora }\end{array}$ & Ukupno & $\begin{array}{l}\text { Zdravstvena škola } \\
\text { Split }\end{array}$ & $\begin{array}{l}\text { Sveučilišni odjel } \\
\text { zdravstvenih } \\
\text { studija u Splitu }\end{array}$ \\
\hline 2 & $3(16)$ & $1(1,1)$ & $2(2,1)$ \\
3 & $13(7)$ & $4(4,3)$ & $9(9,6)$ \\
4 & $27(14,5)$ & $9(9,8)$ & $18(9,1)$ \\
5 & $46(24,7)$ & $24(26,1)$ & $22(23,4)$ \\
6 & $43(23,1)$ & $19(20,7)$ & $24(25,5)$ \\
7 & $35(18,8)$ & $20(21,7)$ & $15(16)$ \\
8 & $15(8,1)$ & $12(13)$ & $3(3,2)$ \\
9 & $3(1,6)$ & $3(3,3)$ & 0 \\
10 & $1(0,6)$ & 0 & $1(1,1)$ \\
\hline
\end{tabular}

$* \chi 2$ test

odgovora na Sveučilišnom odjelu zdravstvenih studija u Splitu (4,3\%).

U Tablici 4 uspoređivali smo znanje i mišljenje o osposobljenosti provođenja kardiopulmonalne reanimacije. Jednakim spajanjem skupina ispitanika prema točnosti odgovora na pitanja znanja, nismo dokazali statistički značajnu razliku u odnosu na odgovore "DA" i "Smatram da mi je potrebna dodatna edukacija" ( $\chi 2$ $=1,76 ; \mathrm{P}=0,780$ ) (Tablica 4). Usporedba skupina s odgovorom "DA" i "Smatram da mi je potrebna dodatna edukacija" zajedno u odnosu na skupinu ispitanika koja je odgovorila s "NE" nije moguća zbog malog broja ispitanika $(\mathrm{n}=15)$.

\section{RASPRAVA I ZAKLJUČAK}

Ovim istraživanjem pokazali smo da ni studenti, a ni učenici nemaju visoko teorijsko znanje o KPR-u, a dobiveni rezultati su zajednički svim sada provedenim istraživanjima (8-11). Istraživanje koje je provedeno 2016. na uzorku od 1.349 studenata zdravstvenih studija, pokazalo da je prosječni ukupni rezultat znanja bio vrlo nizak $(32,7 \pm 13,9)$, a $87,9 \%$ sudionika imalo je vrlo loše znanje (8). Istraživanje koje su 2017. godine proveli Sangamesh $\mathrm{NC}$ i sur. u Indiji, također je pokazalo da je znanje o BLS-u bilo nedostatno (9).

Naše istraživanje je pokazalo da postoji statistički značajna razlika prema ukupnom zbroju ispravnih odgovora između učenika Zdravstvene škole Split i studenata Sveučilišnog odjela zdravstvenih studija u Splitu $(Z=2,96$; $\mathrm{r}=0,217 ; \mathrm{P}=0,003)$. Učenici Zdravstvene škole Split pokazali su veću razinu znanja naspram studenata sestrinstva. Ovdje je bitno istaknuti činjenicu da u $32,5 \%$ ispitanika nije provedena edukacija o KPR-u, što se slaže s rezultatima našeg istraživanja gdje je razlici u znanju doprinijela razlika u nastavnim planovima i programima $(4,5)$. Naime, učenici zdravstvene škole u 4. razredu srednjoškolskog obrazovanja pohađaju predmet Hitni medicinski postupci. Predmet sadrži 37 sati predavanja i 74 sata vježbi koje se odvijaju tijekom cijele školske godine kroz 1 sat predavanja i 2 sata vježbi tjedno. Studenti Sveučilišnog odjela zdravstvenih studija u Splitu pohađaju predmet Anesteziologija, reanimatologija i intenzivno liječenje na 3.

Tablica 4.

Prikaz broja (\%) ispitanika prema ukupnom broju ispravnih odgovora u odnosu na pitanje „Osjećate li ste osposobljeno za pružanje kardiopulmonalne reanimacije?" (,DA“, „NE“, Smatram da mi je potrebna dodatna edukacija)

\begin{tabular}{|c|c|c|c|c|}
\hline \multirow[b]{2}{*}{$\begin{array}{l}\text { Ukupan broj ispravnih } \\
\text { odgovora }\end{array}$} & \multicolumn{4}{|c|}{ Broj ispitanika (\%) } \\
\hline & Ukupno & "DA" & "NE" & $\begin{array}{l}\text { "Smatram da mi je potrebna } \\
\text { dodatna edukacija" }\end{array}$ \\
\hline 2 & $3(16)$ & $1(1,6)$ & $1(6,7)$ & $1(0,9)$ \\
\hline 3 & $13(7)$ & $3(4,8)$ & $3(20)$ & $7(6,5)$ \\
\hline 4 & $27(14,5)$ & $7(11,1)$ & $2(13,3)$ & $18(16,7)$ \\
\hline 5 & $46(24,7)$ & $16(25,4)$ & $3(20)$ & $27(25)$ \\
\hline 6 & $43(23,1)$ & $16(25,4)$ & $5(33,3)$ & $22(20,4)$ \\
\hline 7 & $35(18,8)$ & $14(22,2)$ & $1(6,7)$ & $20(18,5)$ \\
\hline 8 & $15(8,1)$ & $4(6,3)$ & 0 & $11(10,2)$ \\
\hline 9 & $3(1,6)$ & $2(3,2)$ & 0 & $1(0,9)$ \\
\hline 10 & $1(0,6)$ & 0 & 0 & $1(0,9)$ \\
\hline
\end{tabular}

$* \chi 2$ test 
godini preddiplomskog studija. Predmet sadrži 15 sati predavanja, 15 sati vježbi u praktikumu, 15 sati kliničkih vježbi i 20 sati posebnih kliničkih vježbi. Predavanja se održavaju tijekom 2 tjedna (4, 5). Uzevši u obzir nastavni plan i program, kao i vrijeme provođenja istraživanja, studenti treće godine Sveučilišnog odjela zdravstvenih studija su odslušali predmet sa sadržajem kardiopulmonalne reanimacije (5).

Sudionici ovakvih istraživanja smatraju da se edukacija o KPR treba održavati svakih 6 mjeseci do jednom godišnje (35,5\% sudionika), a njih $58,1 \%$ smatra da im je potrebna dodatna edukacija. Ovu izraženu potrebu za edukacijom podržavaju i ostala istraživanja na ovu temu (8-11). Hye Suk K i sur. su 2009. godine, $\mathrm{u}$ istraživanju koje su proveli u Koreji, naglasili: "da bismo razvili pozitivan stav učenika sestrinstva prema uspješnosti KPR-a, moramo ojačati obrazovanje vezano za KPR i stvoriti učinkovite obrazovne programe koji su posebno usredotočeni na praktično osposobljavanje učenika" (10). Istraživanje u Saudijskoj Arabiji je prikazalo slične rezultate, s tim da je $77 \%$ ispitanika izrazilo želju za dodatnim BLS tečajevima, a 78,5\% je podržalo obavezni BLS tečaj (8).

Zbog razlike u edukaciji, odnosno u trajanju edukacije i vremena protekla od edukacije, potrebno je provesti daljnje detaljnije istraživanje o utjecaju tih čimbenika na znanje. Kao i ostali autori u svojim istraživanjima, došli smo do zaključka kako je potrebno omogućiti učestalije edukacije, redovitije provjere znanja $\mathrm{i}$ vještina te poboljšati i kvalitetu same edukacije (3, 8-11). Trenutna edukacija koja se provodi o KPR-u je ispitana kroz istraživanje koje su proveli Vural M i sur. 2016. godine u Istambulu te su, prema rezultatima predložene implementacije, drugačijih oblika edukacije koji bi omogućili stjecanje kvalitetnijih vještina izvođenja KPR-a (11).

Ovo istraživanje ima i nekoliko ograničenja; prvo ograničenje je vezano za sudionike istraživanja, odnosno ispitanici su učenici i studenti bez radnog iskustva u struci. Drugo ograničenje je zbog razlike u nastavnim planovima i programima $(4,5)$. Međutim, bitno je istaknuti kako je ovo prvo istraživanje koje je obuhvatilo populaciju budućih zdravstvenih djelatnika, također s visokim postotkom odaziva ispitanika $(84,1 \%)$.

S obzirom na ispitanu skupinu, učenici Zdravstvene škole i studenti Sveučilišnog odjela zdravstvenih studija $u$ Splitu, nismo pronašli dostatnu literaturu zbog toga što se dostupni publicirani radovi temelje na ispitivanju znanja, stavova i vještina zdravstvenih djelatnika zaposlenih u primarnoj i sekundarnoj zdravstvenoj zaštiti. Istraživanja su pretežno provođena na skupini liječnika i studenata medicine. Medicinske sestre i medicinski tehničari aktivno sudjeluju u provođenju kardiopulmonalne reanimacije, stoga je preporuka da se u buduća istraživanja kao ciljane skupine uključe medicinske sestre na razini Republike Hrvatske.

Zahvaljujemo učenicima Zdravstvene škole $i$ studentima Sestrinstva Sveučilišnog odjela zdravstvenih studija u Splitu na sudjelovanju u ovom istraživanju. Također, želimo se zahvaliti gđi Vesni Čapkun na pomoći pri statističkoj obradi podataka.

\section{Kratice:}

CAEPCR - engl. Knowledge and Attitude of Nurses in the Event of a Cardiorespiratory Arrest ERC - engl. European Resuscitation Council HMP - Hitni medicinski postupci ILS - engl. Immediate Life Support

KPR - kardiopulmonalna reanimacija

\section{NOVČANA POTPORA/FUNDING}

Nema/None

\section{ETIČKO ODOBRENJE/ETHICAL APPROVAL}

Odobrenje Etičkog povjerenstva Sveučilišnog odjela zdravstvenih studija u Splitu: Klasa: 00101/19-01/0001; Ur. Br: 2181-228-07-19-0018.

Odobrenje Etičkog povjerenstva Zdravstvene škole u Splitu: Klasa: 602-03/19-01/59; Ur. Br: 218180/01-19-01.

\section{SUKOB INTERESA/CONFLICT OF INTEREST} Autori su popunili the Unified Competing Interest form na www.icmje.org/coi_disclosure.pdf (dostupno na zahtjev) obrazac i izjavljuju: nemaju potporu niti jedne organizacije za objavljeni rad; nemaju financijsku potporu niti jedne organizacije koja bi mogla imati interes za objavu ovog rada u posljednje 3 godine; nemaju drugih veza ili aktivnosti koje bi mogle utjecati na objavljeni rad./ All authors have completed the Unified Competing Interest form at www.icmje.org/coi disclosure. $p d f$ (available on request from the corresponding author) and declare: no support from any organization for the submitted work; no financial relationships with any organizations that might have an interest in the submitted work in the previous 3 years; no other relationships or activities that could appear to have influenced the submitted work.

\section{LITERATURA}

1. Hunyadi Antičević S, Lojna Funtak I. Napredno održavanje života. 1. izd. Medicinska naklada; Zagreb: 2013.

2. Hunyadi Antičević S, Protić A, Patrk J, Filipović Grčić B, Puljević D, Majhen Ujević R i sur. Smjernice za reanimaciju Europskog vijeća za reanimatologiju 2015. godine. Liječnički Vjesnik. 2016; 138: 305-21

3. Čanađija M. Retrospektivna analiza usvojenog teorijskog znanja medicinskih sestara/tehničara na tečajevima neposrednog održavanja života (Diplomski rad). Zagreb: Sveučilište u Zagrebu, Medicinski fakultet; 2014 (pristupljeno 10. rujna 2019.) Dostupno na: https://urn.nsk. hr/urn:nbn:hr:105:115739.

4. Ministarstvo znanosti i obrazovanja (Internet). Zagreb: Organizacija; c2019 (pristupljeno 20 rujna 2019.). Strukovni kurikulum za stjecanje kvalifikacije medicinska sestra opće njege / medicinski tehničar opće njege; (oko 2 zaslona). Dostupno na: https://mzo.gov.hr/ UserDocsImages//dokumenti/Obrazovanje/ StrukovnoObrazovanje/NastavniPlanoviStrukovno/ZdravstvoiSocijalnaSkrb//7-5_kurikulum-medicinska-sestra-opce-njege-medicinski-tehnicar-opce-njege.pdf.

5. Ministarstvo znanosti i obrazovanja (Internet). Zagreb: Organizacija; c2019 (pristupljeno 20. rujna 2019.). Zajednički obvezni dio preddiplomskog studijskog programa sestrinstva (core curriculum); (oko 2 zaslona). Dostupno na: https://mzo.hr/sites/default/files/migrated/ tekst_za_zajednicki_kurikulum2.pdf.

6. Tíscar-Gonzalez V, Blanco-Blanco J, GeaSanchez M, Molinuevo AR, Moreno-Casbas T. Nursing knowledge of and attitude in cardiopulmonary arrest: cross-sectional survey analysis. Peer J. 2019; e6410.

7. IBM Corp. IBM SPSS Statistics for Windows. Version 23.0.(Software). 2015 (pristupljeno 15. rujna 2019). Dostupno na: https://www.ibm. com/analytics/spss-statistics-software.

8. Mohaissen MA. Knowledge and Attitudes Towards Basic Life Support Among Health Students at a Saudi Women's University. Sultan Qaboos Univ Med J. 2017; 17 (1): 59-65.

9. Sangamesh NC, Vidya KC, Pathi J, Singh A. Awareness, Attitude, and Knowledge of Basic Life Support among Medical, Dental, and Nursing Faculties and Students in the University Hospital. J Int Soc Prev Community Dent. 2017; 7 (4): 161-7.

10. Hye-Suk K, Mi-Sun K, Mi-Hwa P. Analysis of Nursing Students' Knowledge, Attitude and Ability to Perform Cardiopulmonary Resuscitation. Journal of Korean Academy of Fundamentals of Nursing. 2009; 16 (4): 430-7.

11. Vural M, Feridun Koşar M, Kerimoğlu O, Kızkapan F, Kahyaoğlu S, Tuğrul S et al. Cardiopulmonary resuscitation knowledge among nursing students: a questionnaire study. Anatol J Cardiol. 2017; 17 (2): 140-5. 
Summary

COMPARISON OF THE LEVEL OF KNOWLEDGE ON CARDIOPULMONARY RESUSCITATION AMONG STUDENTS OF THE MEDICAL SCHOOL SPLIT AND NURSING STUDENTS OF THE UNIVERSITY DEPARTMENT OF HEALTH STUDIES IN SPLIT

Diana Elez, Rahela Orlandini, Mihajlo Lojpur, Mario Marendić

Aim: To examine the knowledge of the students of the Health school Split and the students of the University Department of health studies in Split in cardiopulmonary resuscitation.

Methods: This study included186 examinees, 94 university students and 92 health school students. A measuring instrument for this study was a CAEPCR questionnaire. Inclusion criteria were age $>18$ years. There were no additional exclusion criteria.

Results: We proved a statistically significant difference in the total number of correct answers to the knowledge questions between the University students and High School students $(Z=2.96 ; r=0.217 ; P=0.003)$. The median total sum of correct answers of students in Medical school Split is 6, and in students from the University Department of Health Studies in Split is 5. There is statistical significance, a weak negative correlation of the total number of positive responses with the age of the subjects ( $\rho=-0.195$; $P=0.008)$. The distribution of the total sums of correct answers according to the 5 statistical groups formed is generally differed between institutions.

Conclusion: Considering the obtained results, we have concluded that the level of knowledge is higher in the students of the Health school, unlike the students of the University Department of Health studies in Split. This result was intensified by the difference in education shown in the curricula. Due to the difference in education, in the duration of education and the time elapsed since education, further research on the impact of these factors on knowledge is needed.

Keywords: CARDIOPULMONARY RESUSCITATION, NURSE, GUIDELINES, KNOWLEDGE

Primljeno/Received: 17. 3. 2021.

Prihvaćeno/Accepted: 26. 4. 2021. 